\title{
Library Ghosts of North Carolina
}

\author{
by Dorothy Hodder
}

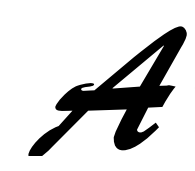

fanciful person might say that every library is haunted by the spirits of the authors of the books that wait on its shelves for readers to share their thoughts and memories. Librarians are not fanciful as a general rule, however, which may lend extra credence to the few who will admit to paranormal manifestations in their buildings. Stories unearthed in a recent informal survey of North Carolina's public library directors on the subject are tantalizingly brief and uniformly tame, in keeping with the quiet, modest, hardworking, conscientious, and discreet image of the typical librarian or scholar.

A good example of a library staff ghost belongs to the Bladen County Public Library in Elizabethtown, North Carolina, which is situated across the street from a cemetery. Library Director Sherwin Rice remembers that "Years ago our janitor, Mr. Stephens, swore he heard books and furniture being moved in the early morning hours before we opened." Clearly this is the spirit of a person who is lost without work, even in the afterlife.

Library director Corki Jones from Hickory reports that her predecessor Elbert Ivey used to check on his old library regularly after his death, and that the elevator would move from floor to floor without assistance during his inspections. None of the staff ever saw him, but they heard footsteps and doors opening and must have recognized him from his habits. Corki herself heard him walking down the hall one night after hours when she was alone in the building. No doubt his restless spirit was relieved to find the new director working late.

An unidentified ghost haunts the Alexander County Library in Taylorsville, according to Director Doris Stephens, although the building is only twenty-five years old and has no major tragedies in its history. Her staff describe a woman in a dark coat who walked past the circulation desk one night after the library was closed and the outer doors were locked, but simply disappeared when they went looking for her. On another occasion a woman walked from a workroom into the staff lounge after closing time-again, nobody could be found. Staff have al so heard someone rattling the locked door to the workroom and tidying shelves in the reference section when the building is closed and the lights are out. Doris has not personally witnessed any of these phenomena in spite of working alone and far into the night on many occasions. "Most of the peculiar noises we hear off and on no doubt are just our resident attic squirrels, who routinely wear combat boots and dance the Highland Fling," is her assessment, but the evidence points to another library staffer who continues to put in time from the beyond.

The New Hanover County Public Library (NHCPL)'s North Carolina Room is 
home to the ghost of a local historian who apparently did not complete her research before her death about twenty years ago. The only person who has ever reported seeing this ghost was an el derly gentleman who volunteered in the department seven days a week as long as his health permitted, who identified her as the deceased researcher. Some of the woman's files turned up on librarian Beverly Tetterton's desk soon after the funeral, but when Beverly thanked bereaved family members for contributing the materials to the collection they each denied having been the one to drop them off. Arthur Myers documented a paranormal presence in the room in The Ghostly Register: Haunted Dwellings, Active Spirits: A Journey to America's Strangest Landmarks (Contemporary Books, 1986).

Although ghostly visits have diminished over the years, staff who work evening shifts in NHCPL's local history department have frequently heard books being pulled off the shelves in the stacks behind them at times when they knew themselves to be alone in the room, and are particularly likely to find the papers of the state's Civil War Governor lying open on the shelf when they check out the disturbance. A former employee (who has since moved to the West Coast) was returning a book to a locked case one evening when the glass door of the case began to shake violently. He sensed a distinct presence that seemed to want access to the case and summoned his courage to apologize for needing to lock it, at which the presence gave a "Hmmmph!" and dissipated. This ghostly behavior is all the more curious because locked file cases are rather commonly found standing open in the mornings when staff come on duty, with Civil War records spread across work tables. Beverly al so complains that the cleaning crews who work after hours do a less-thanthorough job in her room - apparently the ghost disapproves of noise in her domain at any time and hurries the janitors along by unplugging their vacuum cleaners.

NHCPL's headquarters library was under renovation during 2002 and the early part of 2003, and local history materials were moved while the department was expanded. The ghost's attitude toward the upheaval remains to be determined, but since some historical materials in storage in the basement seem to be in regular use without assistance from staff there is reason to believe that she has not been driven from her research. This is good news for staff who find a resident ghost to be an asset for holding the attention of grade-school tour groups, al though as time goes on they observe that children have an increasingly hard time coping with the lack of crime and gore in the story.

Some libraries inherit ghosts when they occupy previously owned buildings. The Beaufort-Hyde-Martin Regional Library headquarters is housed in the old Beaufort County Courthouse (ca. 1789), and claims many eerie stories. The original courtroom is still upstairs, and everyone who enters it reports smelling cigar smoke. The Reference Librarian likes to entertain school children with a story about a horse thief who attempted to evade trial by jumping out the courthouse window and running to the building next door to hide, not realizing that the building next door was the jailhouse. The occasional sound of breaking glass is heard in the library, bearing the story out.

Director Mark Pumphrey reports weird happenings at Polk County Public Library's new Saluda Branch Library. It is in an old turn-of-the-century building that has been many things over the years, including a mercantile store, a café, and apartments. The librarian, the technical services librarian, and several volunteers and library users all claim to hear muted sounds like people talking on a telephone and footsteps on the stairs.

"I think we had a ghost once in Scotland County, but he moved to Ashe County," says Scotland County Director Robert Busko. "Apparently he liked western barbeque better than eastern and the other ghosts were friendlier." Robert's cheerful nonchalance typifies the library professional's respect for the 
privacy and tolerance for the eccentricities of patrons.

A story about a library that ought to be haunted but doesn't seem to be was shared by Pender County Public Library Director Mike Taylor. Mike heard about a public library in the state, not his own, that found two caskets in a crawl space or basement underneath the building when they installed computer wiring in the 1990s. By the state of the human remains in the caskets, they had been there for a very long time. The discovery was duly reported to the proper authorities, but evidently matched no known crime. By one account no one would take responsibility for the bodies or take them off the library's hands; by another the caskets still residing under the library are empty.

The director of the library in question, who naturally wishes to minimize local publicity about the mystery, says she has heard about caskets and loose bones being found under the old library. It was built on the site of an A.M.E. church which had a cemetery beside it, and possibly the library encroached on part of the graveyard. "I never saw or heard any ghosts," she staunchly maintains. "When things get quiet in the new library it sounds as if some heavy-footed creature is tromping on the roof. I am sure it's the building settling."

Mike Taylor is not so easily derailed from his ghoulish enjoyment of this story, however. "Where did the bodies come from?" he speculates. "I wonder if a search of records of unrecovered books, some missing cherished tome from the past, might at last account for two patrons who mysteriously disappeared, supposedly on their way home from the library one night after closing on a moonless, dark night?"

In conclusion, Sampson-Clinton Public Library Director Robin Williford remembered a story her husband told her when he first took her to meet his mother's family in Johnston County. It seems when he was a little boy, about twenty years ago, the Johnston County Library bookmobile accidentally took a turn for the worse and ran - literally ran - through a low brick fence into a rural cemetery. His grandfather thought it was such a sight he actually took him out to see the wreckage. Readers may decide for themsel ves whether they believe that was truly an accident, or a case of excellent library service to a homebound patron. 